http://jmscr.igmpublication.org/home/ ISSN (e)-2347-176x ISSN (p) 2455-0450 crossref DOI: https://dx.doi.org/10.18535/jmscr/v8i2.90

\title{
Comparative study of Blood bank donor infected with HIV \&Hepatitis B infection and Prevalence coal field area Dhanbad, Jharkhand
}

\author{
Authors \\ Dr Sujeet Kumar Tiwary ${ }^{1}$, Dr Ajay Kumar ${ }^{2 *}$, Dr Sunil Kumar Sinha ${ }^{3}$, \\ Dr Binay Kumar Singh ${ }^{4}$, Rupesh Kumar \\ ${ }^{1}$ Tutor, Dept. of Microbiology, PMCH Dhanbad \\ ${ }^{2}$ Professor, Dept. of Pathology, PMCH Dhanbad Cum- Blood Bank in - Charge PMCH \\ ${ }^{3}$ M.O. Cum- Assistant Professor, Community Medicine PMCH, Dhanbad \\ ${ }^{4}$ H.O.D \& Associate Professor, Dept. Of Microbiology, PMCH, Dhanbad \\ ${ }^{5}$ Consultant Microbiologist RNTCP, IRL Itaki Ranchi, Jharkhand \\ *Corresponding Author \\ Dr Ajay Kumar
}

\begin{abstract}
Blood transfusion is an important component of health care and millions of lives are being saved each years through this procedure ${ }^{\{1.2\}}$ in Jharkhand scores of peoples visit blood bank of various hospital and other blood donation center to donate blood. Today very important role play blood banks and saving humans lives. Blood bank collected blood from donors, performing screening test and separated in to components stored, and prepared for transfusion to recipients. ${ }^{\{3,4\}}$ After blood is drawn, screening tests are also performed for evidence of donor infection with Hepatitis viruses $B$ and $C$, human immune deficiency viruses (HIV) 1 and 2. Blood bank In the case of reactive screening result, confirmatory testing should be performed to identify infected blood donors should be informed. This study focus on screening test reactive donors Prevalence to HIV and Hepatitis B infection coal field area dhanbad, Jharkhand.

Materials and Methods: All Study was done at the department of Microbiology PMCH Dhanbad from December 2018 to December 2019 with the help of blood Bank PMCH, dhanbad. This study collected approximately 1195 blood donor's blood sample.This study is done with the name, address, and any other contacts of the Person will be kept secret.

Sample Collection: The blood donor's blood samples collected to be PMCH blood Bank and within one hours transporting Microbiology dept. lab.

Blood Screening Test: Blood screening test examination used Rapid test kitsHIV and Hepatitis B.

Keywords: Blood screening, Hepatitis B, HIV, and Reactive.
\end{abstract}

\section{Introduction}

Blood transfusion is an important component of health care and millions of lives are being saved each years through this procedure. ${ }^{\{5\}}$ In the Jharkhand state scores of peoples visit blood banks of various hospitals and other blood donation centers to donate their blood. Today blood banks play a very important roles in saving human lives. ${ }^{\{6,7\}}$ Blood banks collects blood from various donors, performing screening test and separates blood components and store them in cold chain with the help of refrigerator and 
prepared them for transfusion to recipients. ${ }^{(8,9)}$ After blood is drawn, screening tests are also performed for evidence of donors infection with Hepatitis viruses $\mathrm{B}$ and $\mathrm{C}$, human immunodeficiency viruses (HIV) $1 \& 2$.blood bank In the case of reactive screening result, confirmatory testing should be performed to identify infected blood donors and should be informed to donors. This study focus on screening test reactive donors Prevalence to HIV and Hepatitis B infection coal field areaof dhanbad district of Jharkhand.

Age and Sex Predilection of Donors: In this study all Downers of both genders who were more than 18 years of age were included.

Statistical Analysis: All Data were analyzed with standard statistical method, percentage were computed for all variables results were presented in the form of table and column.

\section{Result}

In our study of a total number of 1195 Blood donor's Blood samples were collected and thoroughly investigated by the Microbiology standard procedure in the Department of
Microbiology of the Patliputra Medical Collage and Hospital Dhanbad. In this Study we found that the total number of Male donors were $875(73 \%)$ and Total number of female donors were241 (According to Table 1). In the age groups of 18 to 33the total number of Hepatitis- B positive were $10,(59 \%)$ and the age group 34 to 48 total number of Hepatitis B positive were $03(18 \%)$ and the age group of 49 to above total number of Hepatitis -B positive were 04(23\%), in our study we have found that the total number of HIV Reactive blood donor samples were 09 , in the age group of 18 to 33 the total reactive blood samples were $02(22.7 \%)$ and the age groupof 34 to48 the total number of reactive blood samples were 04(44\%), In the last age group of 49 to above, the total number of HIV reactive blood samples were 03(33.3\%). In this study this shows that the infection of Blood donor samples Hepatitis B is much higher than HIV. In this study we have found that the highest numbers of HIV reactive blood donors in the age group of 34 to 48 and the age groups of 18 to 33 is the highest Hepatitis B positive blood donor's (According to Table 2 \& 3).

Table 1 Age and Sex wise distribution among total Blood Donor Samples

\begin{tabular}{|c|c|c|c|c|c|c|c|c|c|c|}
\hline \multirow{2}{*}{$\begin{array}{l}\text { Total Number } \\
\text { of Blood Donor } \\
\text { Samples. }\end{array}$} & \multicolumn{4}{|c|}{ Gender. } & \multicolumn{6}{|c|}{ Age Group. } \\
\hline & $\begin{array}{c}\text { Mal } \\
\text { e. }\end{array}$ & $\begin{array}{c}\text { Total } \\
\%\end{array}$ & $\begin{array}{c}\text { Femal } \\
\text { e. }\end{array}$ & $\begin{array}{c}\text { Total } \\
\%\end{array}$ & $\begin{array}{c}18 \text { to } \\
33\end{array}$ & $\begin{array}{c}\text { Total } \\
\%\end{array}$ & $\begin{array}{c}34 \text { to } \\
48\end{array}$ & $\begin{array}{c}\text { Total } \\
\%\end{array}$ & $\begin{array}{r}49 \text { t0 } \\
\text { above. }\end{array}$ & Total \% \\
\hline 1195 & 875 & $73 \%$ & 320 & 27 & 486 & $41.4 \%$ & 455 & $38 \%$ & 254 & $20.6 \%$ \\
\hline
\end{tabular}

Table 2 Total Number of Blood Donor Samples HIV test \& Confirmatory Test

\begin{tabular}{|c|c|c|c|c|c|c|c|c|c|c|}
\hline \multirow{4}{*}{$\begin{array}{l}\text { Total } \\
\text { Number of } \\
\text { Blood } \\
\text { Donor } \\
\text { Samples. }\end{array}$} & \multicolumn{7}{|c|}{ HIV test. } & \multirow{2}{*}{\multicolumn{3}{|c|}{ Hepatitis B. }} \\
\hline & \multicolumn{3}{|c|}{$\begin{array}{c}1^{\text {st }} \\
\text { HIV test }\end{array}$} & \multicolumn{2}{|c|}{$\begin{array}{c}2^{\text {nd }} \\
\text { Confirmatory } \\
\text { Test } \\
\end{array}$} & \multicolumn{2}{|c|}{$\begin{array}{c}3^{\text {rd }} \\
\text { Confirmatory } \\
\text { Test } \\
\end{array}$} & & & \\
\hline & \multicolumn{2}{|c|}{ Combs Test. } & \multirow[t]{2}{*}{$\begin{array}{c}\text { Total } \\
\%\end{array}$} & \multicolumn{2}{|c|}{$\begin{array}{c}\text { Merils Rapid Kit } \\
\text { Test. }\end{array}$} & \multicolumn{2}{|c|}{ Aids scan Rapid kit Test. } & \multicolumn{3}{|c|}{ Rapid kit Test. } \\
\hline & Reactive & $\begin{array}{l}\text { Non- } \\
\text { Reactive }\end{array}$ & & Reactive & $\begin{array}{l}\text { Non- } \\
\text { Reacti } \\
\text { ve }\end{array}$ & Reactive & $\begin{array}{l}\text { Non- } \\
\text { Reactive }\end{array}$ & Positive & $\begin{array}{l}\text { Negativ } \\
\text { e }\end{array}$ & $\begin{array}{c}\text { Total } \\
\%\end{array}$ \\
\hline 1195 & 09 & 1186 & 0.7 & 09 & 00 & 09 & 00 & 17 & 1178 & 1.4 \\
\hline
\end{tabular}


Table 3 Total HIV Reactive Blood Samples \& Total Hepatitis Positive Blood Samples Age Wise distribution

\begin{tabular}{|c|c|c|c|c|c|c|c|c|c|c|c|c|c|}
\hline \multirow{2}{*}{$\begin{array}{lr}\text { Total } & \text { HIV } \\
\text { Reactive } & \text { Blood } \\
\text { Samples. } & \\
& \end{array}$} & \multicolumn{6}{|c|}{ Age Group distribution. } & Total Hepatitis & \multicolumn{6}{|c|}{ Age Group distribution } \\
\hline & $\begin{array}{c}18 \text { to } \\
33\end{array}$ & $\begin{array}{c}\text { Tot } \\
\text { al } \\
\%\end{array}$ & $\begin{array}{c}34 \\
\text { to } 48\end{array}$ & $\begin{array}{c}\text { Total } \\
\%\end{array}$ & $\begin{array}{c}49 \text { t0 } \\
\text { abov } \\
\text { e. }\end{array}$ & $\begin{array}{c}\text { Tot } \\
\text { al } \\
\%\end{array}$ & $\begin{array}{l}\text { Positive Blood } \\
\text { Samples. }\end{array}$ & $\begin{array}{c}18 \text { to } \\
33\end{array}$ & $\begin{array}{c}\text { Total } \\
\%\end{array}$ & $\begin{array}{c}34 \text { to } \\
48\end{array}$ & $\begin{array}{c}\text { Total } \\
\%\end{array}$ & $\begin{array}{l}49 \text { t0 } \\
\text { above }\end{array}$ & $\begin{array}{c}\text { Total } \\
\%\end{array}$ \\
\hline 09 & 02 & $\begin{array}{c}22 . \\
7\end{array}$ & 04 & 44 & 03 & $\begin{array}{c}33 . \\
3\end{array}$ & 17 & 10 & 59 & $\mathbf{0 3}$ & 18 & 04 & 23 \\
\hline
\end{tabular}

\section{Discussion}

Human blood is used for the prevention and treatment of various life threatening diseases. The blood transfusion has been subject to contamination with different human pathogens that may induce a wide variety of risk, especially transfusion such as HIV and Hepatitis B. HIV and Hepatitis B virus transmitted through sexual contact and same injection use by persons. ${ }^{\{10\}}$ Because of these shared mode of transmission, people at high risk for HIV infection and also risk for HBV infection. ${ }^{\{11\}}$ The result of this study have demonstrated the endemicity and occurrence of significant levels of HIV and Hepatitis B infection in blood donors in dhanbad district of Jharkhand. In this study $0.7 \%$ Prevalence of HIV and Hepatitis B virus and 1.4 was reported. The study suggests that we should improveour blood banks screening test techniques and recommend the measures like public awareness of the infection of HIV and Hepatitis B virus.

\section{Conclusion}

HIV and hepatitis B are public health problem in the world. The HIV patients in the whole world approximately about 2.5 to 3.o million worldwide according to (WHO). Hepatitis B virus infection and HIV infection caused nearly a million deaths worldwide. In the whole world, more than 257 million people live with HBV infection according to (WHO). This study focus on HIV 1, \&HIV 2, and Hepatitis B Prevalent among blood donors from Coal field area of dhanbad district of Jharkhand.

Declaration: This study is done with the name, address, and any other contacts of the Person will be kept secret.
Duration of study: One Year.

Acknowledgments: This Research study is permitted by:

Institutional Ethics Committee, Patliputra Medical Collage, Dhanbad.

IEC PMCH Register by: (The Central Drugs Standard Control organization) Director General of Health Services, Ministry of Health \& Family Welfare, Government of India.

\section{References}

1. UNAIDS Data Table 2011. [Accessed on December 28, 2011]. Available from:http://www.unaids.org/en/media/unai ds/contentassets/documents/unaidspublicat ion/2011/JC2225_UNAIDS_datatables_en .pdf.

2. UNAIDS World AIDS Day Report 2011. [Accessed on December 28, 2011]. Available from: http://www.unaids.org/en/media/unaids/co ntentassets/documents/unaidspublication/2 011/JC2216 World AIDS Day Report 2011 datatables_en.pdf. [Accessed on December 28, 2011]. Available from:

3. Kannangai R, Nair SC, Shridharan G, Prasannakumar S, Daniel D. Frequency of HIV type of infections among blood donor population from India: A 10-year experience. Indian J Med microbial. 2010; 28:111-3. [PubMed].

4. Lange JM, Van den Berg H, Dooren LJ, Vossen LM, Kuis W, Goldsmith J. HTLV III/LAV infection in nine children infected with a single plasma donor: Clinical outcomes and recognitions patterns of viral proteins. J Infect Dis. 1986; 154:171-4. [PubMed]. 
5. WHO. Acquired immunodeficiency syndrome (AIDS). Proposed criteria for interpreting results from western blot assays for HIV-1, HIV-2 and HTLVI/HTLV-II. Weekly Epidemiol Rec. 1990; 65:281-98. [PubMed].

6. Dubey A, Sonker A, Chaurasia R, et al. Knowledge, attitude and beliefs of people in North India regarding blood donation. Blood Transfus 2014; 12 (Suppl 1):s21-7. doi:10.2450/2012.0058-12 Google Scholar

7. Siromani U, Thasian T, Selvaraj KG, et al. Determinants which influence to donate blood voluntarily at a northeast district of the state of Tamil Nadu, South India. Indian J Community Med 2014;39:250. doi:10.4103/0970-0218.143031 Google Scholar

8. Yuan S, Hoffman $\mathrm{M}, \mathrm{Lu} \mathrm{Q}$, et al. Motivating factors and deterrents for blood donation among donors at a university campus-based collection centre. Transfusion 2011;51:2438-44. doi:10.1111/j.1537-2995.2011.03174.x

Google Scholar.

9. Pope C, Ziebland S, Mays N. Qualitative research in health care. Analysing qualitative data. BMJ 2000;320:1146.doi:10.1136/bmj.320.7227.114 FREE Full Text Google Scholar.

10. Sanner MA. Exchanging spare parts or becoming a new person? People's attitudes toward receiving and donating organs. Socal Sci Med 2001;52:14919.doi:10.1016/S0277-9536 (00)00258-6 Cross Ref Pub Med Web of Science Google Scholar.
11. Gillespie TW, Hillyer CD. Blood donors and factors impacting the blood donation decision. Transfuse Med Rev 2002;16: 115-30. doi:10.1053/tmrv.2002.31461 Cross Ref Pub Med Web of Science Google Scholar.

12. Bednall TC, Bove LL. Donating blood: a meta-analytic review of self-reported motivators and deterrents. Transfuse Med Rev 2011;25:317-34. doi:10.1016/j.tmrv.2011.04.005 Cross Ref PubMed Google Scholar. 